\title{
INFLUXOS POLÍTICOS EM PARQUE INDUSTRIAL: A FORMA LITERÁRIA DA DISSIDÊNCIA
}

- JOÃO CARLOS RIBEIRO JR.

\section{RESUMO}

O artigo explora as linhas de força que atravessam a fatura de Parque industrial, de Patrícia Galvão, observando seus aspectos políticos. $\mathrm{O}$ tom panfletário da obra costuma gerar em seus leitores, inclusive os admiradores da escritora, certo desconforto, pois seu alinhamento doutrinário ora é visto como mera propaganda, ora como submissão intelectual. A análise de seu viés programático e de suas contradições, entretanto, revela escolhas críticas pouco notadas até agora. Repassaremos, então, algumas características do realismo socialista, estética ascendente no período da escrita deste livro, ressaltando as diferenças dela com o material formalizado. Retomaremos também as principais características da produção literária anarquista do início do século, estabelecendo uma familiaridade pouco notada pela fortuna crítica e, por fim, analisaremos uma passagem decisiva do romance para destacar a imprevista recepção do pensamento de Rosa Luxemburgo no Brasil.

Palavras-chave: modernismo, Patrícia Galvão, romance proletário, realismo socialista, anarquismo, Rosa Luxemburgo.

\section{ABSTRACT}

This article explores the main guidelines that go through the aesthetics makings of Patrícia Galvão's novel Parque industrial, focusing on its political aspects. The work's overall politically motivated tone tends to generate a certain discomfort on its readers, including the writer's admirers, because its political commitment is viewed sometimes as sheer propaganda and other times as intellectual submission. Nevertheless, the analysis of the work's programmatic bias and contradictions reveals critical choices hitherto hardly noticed. We will review then some features of the socialist realism, an aesthetics that was rising during the period in which the book was written, and emphasize the differences between its traits and the work under examination. We will also establish a relationship, rarely perceived by the critical studies, between the main characteristics of the anarchist's literary production from the beginning of the 20th century and Galvão's novel. Finally, we will examine a decisive excerpt from the novel in order to highlight the unforeseen reception of Rosa Luxemburg's thought in Brazil.

Keywords: modernism, Patrícia Galvão, proletarian novel, socialist realism, anarchism, Rosa Luxemburg 
$\mathrm{P}$ arque industrial realiza o projeto modernista de modo sui generis. O romance confronta o realismo formal com suas cenas de flagrante síntese, frases curtas, períodos impactantes, uso seletivo do coloquial, incorporação de linguagem popular. O processo penoso ao qual a narrativa se dedica despreza o recorte individual, nela é valorizada o despertar de uma classe. Sua dupla filiação (política e estética) combina características da prosa da década de 1920 com o fenômeno do romance proletário. Escrito em um momento de reclusão política da autora, a jovem Patrícia Galvão, o livro expõe evidentes intenções didáticas. Era para ser lido por trabalhadores. Tinha, no entanto, pretensão reabilitadora: também se destinava a dirigentes pecebistas. A partir desta interlocução, é possível notar que Pagu defendia um modelo de partido sensivelmente distinto do que aquele que ela conhecera.

O livro foi publicado em 1933, época em que as decisões do VI Congresso da Internacional Comunista de 1928 ainda transformavam o PCB. O encontro realizado em Moscou substituiu tática de frente única para a de classe contra classe, política que em seus elementos essenciais continha a tese do socialfascismo, segundo a qual a social-democracia era vista como uma variante da direita com potencial nocivo muito mais grave, pois cumpria um papel de dissimulação política. Dessa tese derivou a orientação para que eventuais pactos políticos ocorressem diretamente com os operários socialistas, apenas em casos muito particulares e no espaço dos sindicatos de base, nunca com alianças entre as organizações partidárias (PINHEIRO, 1992). Em suma, firmou-se a base para uma postura sectária. Complementada, neste mesmo VI Congresso, pela oficialização da política de "bolchevização" dos partidos comunistas do mundo todo, a partir de então "o papel dos trabalhadores na liderança desses partidos passou a ser deliberadamente ressaltado" (HOBSBAWM, 2013, p. 239) e a figura do operário, em muitos países, foi alçada ao mítico lugar do predestinado (DEL ROIO, 1990).

A repercussão dessas diretrizes levou o PCB ao isolamento. O Partido, que até então conquistara certo espaço institucional com a construção do Bloco Operário e Camponês (BOC), adotou posicionamentos que acabaram por dissolver o arco institucional que criara (CARONE, 1982, p. 9). O BOC era resultado de uma política que prezava a dinâmica local da luta política. Mais do que efetivar uma tentativa de frente única, ou seja, uma coalizão de diversos setores do proletariado do campo e da cidade, ambicionava corresponder a uma leitura do Brasil, de seu contexto e história (KAREPOVS, 2006). Ele representava o esforço de articular tática e estratégia vinculadas às características da "realidade brasileira", termo que se tornaria corrente entre a intelectualidade dos anos 1930. A virada imposta pelo Comintern, e executada pela seção latino-americana sediada na Argentina, enterrou não apenas uma experiência que avançava no aspecto organizativo militante e na institucionalidade, mas também a intenção de combinar o 
marxismo com as características locais, iniciativa que ganhava corpo, com todas as limitações inerentes ao tempo histórico de então e às deficiências de uma jovem classe operária organizada. Durante a vigência desta política, conhecida como obreirismo (1929-1934), saíram do Partido, junto com seus intelectuais, os esforços de compreensão teórica da formação nacional. Caio Prado Jr. corrigiria essa falha posteriormente, mas sem que o Partido acompanhasse sua elaboração ou aderisse às suas ideias (RICUPERO, 2000).

Uma das consequências imediatas dessa bolchevização tardia do Partido foi a absoluta marginalização do PCB no principal tópico do debate político nacional em 1931. O Partido mal participou das discussões sobre a convocação de uma assembleia nacional constituinte, pois considerava a proposta paliativa e enganosa. Sua perspectiva era a organização de greves e manifestações que criariam as "bases para uma revolução popular, operária e camponesa" (DEL ROIO, 1990, p. 200). O giro que levou o Partido do BOC ao obreirismo o enfraqueceu durante a "primeira experiência de criação, no país, do poder e da política nacionais", como bem observou Gildo Marçal Brandão (1997, p. 87). Essas diretrizes compõem o panorama doutrinário de Parque industrial.

No panorama estético, o debate sobre o romance proletário ganhava relevo no Brasil. Em julho de 1933, mesmo ano de lançamento de Parque industrial, Jorge Amado publica Cacau, sobre a vida dos trabalhadores das fazendas do sul da Bahia. Segundo a nota autoral de abertura, o livro teria sido escrito com "um mínimo de literatura para um máximo de honestidade". Amado encerra este comentário com a sugestiva pergunta: "Será um romance proletário?". No mês seguinte, Amando Fontes foi alçado à popularidade literária e dividiria o posto de best-seller com Amado ao colocar na praça o romance Os Corumbas, que narra a transição traumática de uma família do interior de Sergipe a uma Aracaju de incipiente industrialização. Também Serafim Ponte Grande, de Oswald de Andrade, foi posto em circulação nessa época. O debate que se seguiu a estes lançamentos pôs em foco a noção de "romance proletário" (BUENO, 2006, p. 159). Em anos anteriores, a entrada no país de obras que tematizavam a desigualdade social já havia formado um público significativo de leitores afeitos a escritores simpáticos ou engajados na esquerda, como Boris Pilniak, Panai Istrat, Ilya Eherenburg, Fiodor Gladkov, Michael Gold, Upton Sinclair e Jack London, todos citados por Antonio Candido em "A revolução de 1930 e a cultura" (CANDIDO, 2006b, p. 229). Foi nesta época também que cresceu o número de publicações brasileiras com orientação marxista, inclusive com pequenas editoras voltadas a este perfil (exemplos: a Marenglen e Unitas), e da voga de noções tiradas do vocabulário comunista militante, tais como luta de classes, mais-valia, proletariado, moral burguesa. O realismo socialista ganhava projeção no mesmo período. No cruzamento de influências, entretanto, esta estética não é um vetor decisivo em Parque industrial. Vejamos. 
As origens políticas e teóricas do realismo socialista remontam aos primeiros debates sobre organização partidária e suas relações com a imprensa militante. $\mathrm{O}$ texto mais célebre desta polêmica foi escrito por Lenin em 1905. A organização do partido e a literatura do partido legará às discussões posteriores a ideia de partiinost na criação literária. O termo significa "espírito de partido" e resume o papel dos escritores comprometidos: conduzir seus trabalhos para a causa proletária geral, indissociando a escrita de outras tarefas militantes. O líder bolchevique sustentava que a "literatura" do partido deveria ser completamente livre desde que não atentasse contra as orientações políticas oficiais. Seu ponto de vista fundamentava-se em uma noção de liberdade ao mesmo tempo abrangente e restritiva: argumentava que quem quisesse escrever com plena liberdade poderia fazê-lo na imprensa partidária. Contudo, se o partido considerasse seus princípios ou programa afrontados, teria garantida a liberdade de excluir de seus quadros a voz divergente, uma vez que a liberdade de associação dava às organizações o direito de decidir sobre a permanência de seus próprios membros. Como se vê, o termo "literatura" em Lenin é ambíguo. Tanto pode abranger os textos argumentativos publicados nos jornais social-democratas como também, e assim ele foi lido por muitos seguidores, se referi à criação artística. Há autores como Vittorio Strada que identificam no partiinost de Lenin uma das raízes do autoritarismo de Andrei Zhdanov, o principal dirigente do realismo socialista (STRADA, 1989). Há outros, como Terry Eagleton, que não enxergam qualquer relação entre o texto de Lenin e as arbitrariedades posteriores no campo da arte (EAGLETON, 2011). O fato inequívoco, no entanto, é que na cultura comunista o debate sobre a liberdade da criação literária e as formas de engajamento que ela pode assumir surgiu associado ao debate sobre a organização do partido. Fundamentalmente, Parque industrial faz da forma partido elemento estrutural de sua narrativa. Chegaremos a este ponto.

Antes, passemos pela revolução russa, processo no qual as possibilidades de criação ganharam uma intensidade própria e o debate no campo artístico tomou um sentido particular: as formas artísticas tornaram-se veículos de comunicação e educação revolucionárias. A literatura, o teatro e o cinema eram usados com tais fins. Os cartazes construtivistas desta época ilustram bem a sintonia entre vanguarda política e vanguarda artística. O desdobramento do processo revolucionário mostrou que haveria certa correspondência dessa interação vanguardista com a situação econômica. Nos primeiros anos, marcados pela guerra civil interna, não havia espaço para quem defendesse a arte pela arte: a opção pelo compromisso político era vital. Neste tempo, prevaleceu no campo artístico o Proletkult, criado durante a revolução e que atingiu grande importância devido à variedade de experiências e alcance. $\mathrm{O}$ nome do movimento, tornado posteriormente uma instituição ligada ao comissariado da educação, sintetiza o ponto de vista do projeto de seus participantes: o estabelecimento de uma 
cultura proletária. Seus dirigentes pregavam a criação de uma literatura que fosse estritamente classista. As obras de arte anteriores à revolução eram vistas de duas formas: havia os que defendiam a sua completa negação, abandonando-as no passado burguês; havia também aqueles que viam utilidade na arte burguesa, desde que repassadas por uma avaliação de caráter marxista (ANDRADE, 2010, p. 154). Essa posição era defendida pelos membros mais conhecidos, Bogdanove Lunatcharsk. Lenin e Bukharin discordavam da ideia de uma cultura estritamente proletária, Trotsky também. O líder do exército vermelho defendia a colaboração dos chamados "companheiros de viagem", artistas de extração burguesa que seriam aliados no processo de luta e transição (TROTSKY, 2007, p. 65). Com a instauração final do comunismo e o fim da divisão da sociedade em classes sociais, não faria sentido pensar em uma cultura proletária. As divergências entre os principais dirigentes bolcheviques e, sobretudo, o grau de autonomia que alcançara o Proletkult geraram uma oposição no comitê central do Partido que enfraqueceu o poder de influência deste movimento.

Outra organização influente na década de 1920 na União Soviética foi a RAPP (Associação Russa de Escritores Proletários), que, com mudanças de nomes e diretrizes políticas, manteve-se ativa de 1925 a 1932. Os participantes da RAPP eram conhecidos pelo sectarismo e pela perseguição aos "companheiros de viagem". Eles rejeitavam qualquer literatura que não fosse partidarizada. A RAPP contou com o apoio da direção política soviética quando esta avançava nas práticas de exclusão e criminalização de divergências. O núcleo de Stalin concentrava cada vez mais poder neste período (1928-1932), quando houve o abandono da NEP em favor do primeiro plano quinquenal. A ideia de partiinost, o espírito de partido leninista, foi fortemente instrumentalizada nesse contexto, em que o governo impulsionava uma alteração profunda na fisionomia econômica do país. Junto com a coletivização rural forçada, havia a política de organizar caravanas de visitas aos novos parques industriais, fazendas coletivas, usinas e construções de infraestrutura "com o objetivo de apre(e)nder a realidade do recém-gerado homo sovieticus e promovê-la" (ANDRADE, 2010, p. 159).

Em 23 de abril de 1932, uma reunião do comitê central do Partido decretaria o fim de todas as associações literárias da União Soviética. A decisão extinguia a diversidade de experiências da década anterior e criava uma instituição, a União dos Escritores Soviéticos, que deveria controlar a produção literária de todo o país. Foi neste contexto que surgiu pela primeira vez o termo "realismo socialista", tornado dois anos depois o nome da estética oficial do regime. Se nos apegássemos somente à cronologia, a obra de Patrícia Galvão já não poderia ser classificada simplesmente como realismo socialista. Mas não é apenas isso que conta. Ao entrar nesse assunto, Bianca Manfrini menciona certo desconforto que a crítica frequentemente expõe quando trata de Parque industrial, a de que seu partidarismo enfraquece o romance proletário (MANFRINI, 2011). A autora 
acredita que algumas características do realismo socialista estão praticamente ausentes do livro: o herói positivo, a visão apologética da modernização' enredo mítico no qual os "guias geniais" (Lenin e Stalin) aparecem para indicar o caminho correto ao protagonista. Apesar disso, Manfrini concede que em certos momentos o romance de Pagu recai num tipo de explicação "à maneira do realismo socialista" e identifica nesses momentos, sobretudo os considerados mais didáticos, uma fraqueza, ainda que, no geral, ela seja superada pela "força de suas imagens" (MANFRINI, 2011, p. 42).

É praticamente lugar comum entre os leitores de Pagu a tese de que a ação política coletiva resgata os personagens da inconsciência e do embrutecimento. Por este aspecto, mais uma característica do realismo socialista está ausente: $\mathrm{o}$ clichê de uma classe autoconsciente e unificada. Em seus primeiros capítulos, há uma reunião na qual trabalhadores de diversas categorias participam. Nela, os agentes de polícia tentam intervir para que o encontro termine rapidamente, postura logo denunciada pelos trabalhadores mais interessados na organização coletiva. Ademais, as trajetórias divergentes determinadas por desníveis de consciência expõem uma diversidade que foge ao esquema simplesmente apologético da classe.

O partidarismo de Parque industrial é muito associado ao empobrecimento artístico (inseparável do político) a que as áreas de influência dos PCs foram submetidas a partir do processo de centralização do poder na União Soviética e eliminação de divergências. Em parte, o livro registra consequências desse processo, até porque o realismo socialista, com o consequente engessamento criado pelo zhdanovismo, não surgiu em uma reunião de Politburo, mas foi resultado de um processo histórico e possui suas raízes em produções e debates anteriores. Patrícia Galvão, quando escreveu seu primeiro romance, certamente foi influenciada por obras que estiveram no trajeto que levou a literatura russa ao Primeiro Congresso dos Escritores Soviéticos de 1934. O romance Cimento (1925), de Fiodor Gladkov, tomado como modelo pelos entusiastas do realismo socialista, consta da lista do Deops de livros apreendidos na casa de Pagu em 1935 (ANDREUCCl, 2006, p. 227). Por outro lado, a maneira como o compromisso político comparece à obra de Pagu restaura vínculos com a tradição literária militante no Brasil. É provável que não tenha sido intenção da autora promover essa conexão, mas as características da obra o fazem. Este livro curto e aparentemente simples em sua concepção, escrito em um momento histórico de mudança estrutural do país, captou contradições da vida social operária. A retomada de uma tradição anarquista de dentro do PCB em franco processo de stalinização testemunha essa complexidade.

A memória das lutas operárias é passada de uma geração a outra de maneiras muito diversas. Quando um instrumento político (jornal, partido, sindicato, associação, movimento etc.) conta com alguma longevidade, a permanência
[1] A modernização capitalista de fato aparece no romance como a irrupção da sociedade de classes, com a reificação dos seres humanos e a fantasmagoria das coisas. A maquinaria industrial é retratada de forma negativa. Ocorre que no ambiente de instauração da sociedade socialista o entusiasmo com a modernização possui um sentido diverso do seu correlato capitalista, mesmo que a matriz prática seja a mesma, o que explicaria a importância, no mundo soviético, da dimensão mítica acompanhar a crença industrialista. 
ou mesmo a retomada de determinadas práticas são bastante comuns. $\mathrm{O}$ reconhecimento dos pioneiros ou de referências em momentos-chave também é importante para fortalecer o sentido histórico das ações e promover a mística que vincula o existente a algo transcendente. Isso acontece quando juventudes partidárias cantam a Internacional antes ou depois de encontros, por exemplo, ou quando uma ocupação no centro de São Paulo batiza o prédio recém-tomado com o nome de revolucionários do passado. Ideias, práticas e mesmo emoções permanecem porque são transmitidas de diversas maneiras. Com isso em mente, se observarmos a tradição literária produzida em solo nacional, Pagu, de certa forma, reata em Parque industrial um elo entre comunismo e anarquismo. Nas primeiras décadas do século XX no Brasil, o anarquismo foi a corrente ideológica que protagonizou importantes lutas sociais e sindicais nos centros urbanos. Entre as contribuições dos movimentos anarquistas, que vieram junto com a imigração de mão de obra estrangeira, está o uso de textos literários para divulgação de suas políticas. Na década de 1930, quando o trabalhismo já despontava como ideologia dominante e no campo da esquerda o anarquismo perdia definitivamente as condições de papel hegemônico no movimento operário do século XX, Pagu escreveu este romance de propaganda que remete aos textos dos jornais anarquistas das décadas anteriores. O romance não foi o gênero privilegiado nas produções anarquistas de que falamos. Publicados sobretudo em jornais de colônias imigrantes, alguns em italiano ou espanhol, as línguas de origem dos escritores e do público a que se destinavam, esses textos eram motivados pela intenção educadora de explorar as contradições da luta de classes em suas narrativas curtas. Os organizadores da coletânea mais abrangente desta produção no Brasil acreditam que a escolha pelo conto se explica tanto pela negação, por parte dos escritores, do "ritmo de radiografia da vida burguesa" que teria o romance, quanto pela "concepção de herói" deste gênero, que acabaria por desvincular o personagem central do que se pretendia explorar primordialmente, uma literatura "marcada com o peso biográfico dos heróis anônimos que então emergiam para a História" (PRADO; HARDMAN, 2011, p. XVI).

Outra característica importante do texto de ficção anarquista é que a figura do autor, tão valorizada tradicionalmente, fica relativamente diminuída no sistema do qual o texto faz parte. $O$ aspecto doutrinal da arte ácrata aparece em sua feição de propaganda, imediatamente, e também na noção de que todos os indivíduos são plenos, capazes de ser políticos e artistas, produzindo coletivamente e orientados pelo mesmo ideal. É bastante frequente nos textos sobre Parque industrial a informação de que Pagu adotou o pseudônimo Mara Lobo por imposição do Partido, que não aceitaria a associação da sigla a uma pessoa para a qual sua direção havia pouco determinara o ostracismo. Se confirmada essa história, a direção do Partido curiosamente colaborou, com a imposição do pseudônimo, para que a publicação tivesse mais essa familiaridade 
com a literatura anarquista.

Acresce-se ainda o fato de que a "relação entre o escritor e o texto é mediada pelo depoimento e a emoção, mais pela intuição que pela escritura" (Idem, p. XX). Nisso o romance de Pagu se conecta, por um lado, à estética proletária anarquista, mas, por outro, se desprende. Pelos motivos autobiográficos (desejo de readmissão, experiência operária degradante, testemunho da morte de um companheiro) presentes na obra, é possível dizer que o texto é mediado pelo depoimento e pela emoção da própria autora. Contudo, pela intenção formal, não é possível dizer que a "intuição" se sobreponha à "escritura". Em termos de elaboração literária, as intenções formalizadas em Parque industrial, que está vinculado à vanguarda artística do modernismo, são muito mais complexas, embora seu aspecto de obra como produto de experiência coletiva que possui uma "temática determinada, uma duração narrativa muito escassa e uma exposição ideológica como base" (Idem, p. XXVIII) também a vincule aos anarquistas. Para fechar as comparações, Parque industrial encerra uma moral da história com forte sentido ético (a consciência de classe liberta), algo bastante comum nas narrativas mencionadas.

Outra vertente captada pelo romance, dentro do campo comunista, é mais cifrada. Tem a ver com a presença de Rosa Luxemburgo na obra e, se não é capaz de tirar do romance a aparência de peça de propaganda ideológica, material mais publicista do que literário, ao menos matiza uma afirmação corrente e sintetizada na ideia de que o pior do livro é "o simplismo partidário, cuja visão estereotipada decorre do catecismo comunista" (ASCHER, 1994). A recorrência de Rosa Luxemburgo em Parque industrial não é fortuita, há consonância entre as ideias da revolucionária e a narrativa, estruturada pela relação entre consciência de classe e processo histórico. Essa problemática ocupou (ainda ocupa) parte importante do pensamento marxista e Luxemburgo elaborou uma contribuição decisiva para o tema, fruto de polêmicas que de certa forma repercutem até os dias atuais.

É célebre, por exemplo, a formulação de Karl Kautsky a respeito do partido como exclusivo produtor de consciência e, consequentemente, como o criador do movimento revolucionário. Convicto de que "a consciência socialista moderna só pode se desenvolver sobre a base de um profundo conhecimento científico", alheio, evidentemente, ao proletariado, pois criado pela "intelectualidade burguesa", a consciência revolucionária era tida como algo introduzido de fora para dentro do movimento operário (apud LENIN, 2006, p. 144). Lenin invoca Kautsky, reconhecido em seu tempo como uma das maiores autoridades em teoria marxista, porque compartilha com o dirigente alemão o ceticismo a respeito do impulso revolucionário das massas. Segundo Lenin, se deixado à sua própria experiência, o proletariado atingiria apenas uma consciência sindical. São os intelectuais revolucionários os responsáveis pela teoria capaz de guiar o 
movimento operário (LENIN, 2006, p. 135). A importância da consciência sindical não é negada, mas reconhecida em suas limitações. Sua maior importância é ser um meio pelo qual a social-democracia cultivaria a compreensão totalizante do processo de produção e exploração capitalista. O promotor dessa elevação do entendimento dos sujeitos sobre o papel histórico que lhes cabe é o partido de vanguarda, constituído por revolucionários profissionais.

Lenin escrevia enquanto seu partido atuava sob a repressão do czarismo. A forte vocação conspirativa era incontornável e o trabalho clandestino uma necessidade da sobrevivência, o que impunha aos seus membros a especialização na divisão de tarefas, acompanhada de alto centralismo. Algumas das questões candentes do Que fazer? (1902) serão retomadas e aprofundadas nos textos reunidos em Um passo à frente, dois passos atrás (1904). É contra as teses principais deste texto que Rosa Luxemburgo, em seu Questões de organização da social-democracia russa (1904), defenderá seus princípios democráticos e que as fronteiras entre a vanguarda e a classe fossem menos rígidas. Este texto é um libelo a favor da criatividade revolucionária das massas. Rosa entende a social-democracia como um movimento socialista de novo tipo, distinto das organizações de conspiradores do período histórico precedente. O partido, portanto, não era visto como uma vanguarda ligada ao movimento da classe operária, mas como o próprio movimento da classe operária. Sobre o centralismo de Lenin, ela é categórica:

As mais importantes e fecundas mudanças táticas dos últimos dez anos não foram "inventadas" por determinados dirigentes do movimento e, muito menos, por organizações dirigentes, mas foram sempre o produto espontâneo do próprio movimento desencadeado. (LUXEMBURGO, 2011, p. 160)

A consciência de classe é vista a partir de uma inversão hierárquica. Ao contrário de atribuir aos dirigentes intelectuais (mesmo aqueles saídos dos meios proletários) um importante papel de comando no movimento, é o próprio movimento que deverá constituir-se em comando intelectual. Nas formulações de Rosa, a relação vanguarda partidária-movimento operário ganha densidade e o panorama da educação política fica mais complexo, já que a primazia do conhecimento revolucionário não é tomada como exclusividade da intelligentsia engajada. A ela, por este ponto de vista, caberia:

esclarecer a massa sobre seus interesses históricos, muitas vezes obscurecido pela ideologia dominante, e não em comandá-la, com base em um saber elaborado fora da classe que, eternamente presa às reivindicações imediatas, nunca conseguiria universalizar 
os seus interesses (LOUREIRO, 2004, p. 72).

É a classe que colhe da experiência histórica do movimento operário um aprendizado próprio que nenhuma organização poderia lhe insuflar. Ainda que o trabalho doutrinário do partido seja importante, é bom frisar, porque os anos de propaganda da social-democracia russa mostraram-se essenciais no processo que culminou na revolução de 1905, o verdadeiro sujeito revolucionário seriam as massas (LOUREIRO, 2004, p. 73). A possibilidade de triunfo do socialismo passaria pela capacidade de elas tomarem para si a teoria marxista, tornando-a um conhecimento transformador e ao mesmo tempo produtor da consciência de classe baseada na experiência, invenção e transformação. Nesse processo é formado o dirigente revolucionário, de dimensão coletiva e legitimidade fundamentada na prática:

o único sujeito a que agora cabe o papel de dirigente é o eumassa [Massen-Ich] da classe operária, que em todo lugar insiste em poder fazer os seus próprios erros e aprender por si mesmo a dialética histórica (LUXEMBURGO, 2011, p. 175).

Essa forte noção de autonomia e ação criativa fundamenta a ideia de democracia em Rosa Luxemburgo. A dirigente polaco-alemã não desvaloriza a energia militante dos bolcheviques russos, como já ressaltamos, mas ao longo de seus escritos ela demonstrou como isso era insuficiente para a instauração do socialismo. As massas possuem inúmeras formas de combate, revolta, manifestação, crítica e organização. No confronto de suas escolhas com seus próprios erros elas pavimentam alternativas e fazem novas escolhas. Quanto a isso, não há fórmula positivista de sucesso, mas a nutrição de uma memória coletiva dos de baixo, de onde expectativas e conhecimento efetivo brilharão para que sejam reapropriados. É deste modo que a ideia de democracia tornase essencial, pois nesses processos o movimento-massa decide por si mesmo, desperta no passado o resgate da própria vontade, homenageia seus mortos com a vitalidade do contra-ataque porque sente concretamente o fato do inimigo continuar a vencer, como constatou e lastimou Benjamin em sua sexta tese sobre a História (BENJAMIN, 1985, p. 224). Aí está uma noção plena de autoeducação revolucionária na qual a separação rígida entre vanguarda e classe inexiste e assim tanto a democracia como o aprendizado resultam em conceitos dinâmicos porque baseados na ação. Parte do pensamento de Rosa Luxemburgo privilegia um eixo estratégico configurado em uma "pedagogia dialética da luta" (LÖWY, 2014, p. 29), a partir da qual o movimento operário orienta sua ação articulando forças estruturadas em consciência de classe, organização e educação política. São esses os elementos que encontraremos na principal cena 
[2] Trata-se de "Estacionamentos e progressos do marxismo". In: O marxismo. São Paulo: Unitas, 1933, p. 177-189. A editora Unitas foi fundada por militantes trotskistas brasileiros reunidos em torno de Mário Pedrosa, Aristides Lobo e Lívio Xavier.

[3] Os principais textos polêmicos de Rosa foram publicados nos anos 1920 na França. http:// www.collectif-smolny.org/article. php3?id_article $=508$ de ação revolucionária de Parque industrial, a greve contra a carestia irrompida no capítulo "Habitação coletiva", como veremos.

Ainda está por ser descoberto o documento histórico que ilustrará os rastros de leitura de Patrícia Galvão e que promoveram os primeiros encontros dela com Rosa Luxemburgo. Se esses contatos iniciais de Pagu com as teses da pensadora, já mártir da revolução, foram baseados em textos escritos, sabe-se que não foi em língua portuguesa, já que o primeiro registro de Rosa publicado em português no Brasil é de $1933^{2}$ (CARONE, 1986, p. 113), mesmo ano de Parque industrial. Como a leitura nos meios operários nem sempre é direta e muitas vezes os membros de organizações aprendem a partir da leitura de terceiros, também é possível que Pagu tenha conhecido as ideias de Rosa por meio de conversas com camaradas e pessoas próximas.

Todavia, Pagu era uma militante que vinha de uma tradição de leitura considerável, cuja voracidade era coerente com os maiores anseios de atualização dos modernistas, por isso não seria absurdo pensar que a jovem lera Rosa em língua francesa, familiar à intelectualidade de então, tanto da vanguarda artística quanto da política, por onde transitou. A língua espanhola também é possível e este encontro pode ter ocorrido na passagem por Buenos Aires, espécie de capital latino-americana da Internacional Comunista. Montevidéu era outro polo importante na cartografia militante, Pagu e Oswald de Andrade estiveram por lá. O próprio Oswald, habitué de círculos intelectuais franceses na década de 1920, pode ter tido informações sobre Rosa em suas passagens por Paris, centro político e cultural com vasta produção editorial, inclusive das obras de Luxemburgo. ${ }^{3}$ Entre eles, o polêmico manuscrito sobre a Revolução Russa no qual ela critica, entre outras coisas, a dissolução da Assembleia Constituinte e contra o qual Lenin escreveu uma furiosa resposta, apontando os "erros" de Rosa e acusando Paul Levi, companheiro dela que resolveu divulgar postumamente o texto, de oportunista insignificante.

Muitas são as vias pelas quais Pagu pode ter se encontrado com o pensamento de Luxemburgo. Sabemos que sua biblioteca (por volta de 1935) não era sectária. Nos prontuários do Deops com os registros de livros apreendidos em sua casa, há obras de Trotsky, por exemplo, quando ela ainda não havia decidido romper com o Partido, o que só ocorreria em 1939. Por um outro registro policial também é possível saber que na cidade de Santos, justamente na época em que Pagu fazia trabalhos políticos, dois importantes comunistas discutiam as ideias de Rosa Luxemburgo. São Adolfo Roitman e Rosa Brickman. Ele diz em uma carta para a futura esposa que pretende traduzir Reforma ou revolução?. A moça, em resposta de 3 de dezembro de 1931, o aconselha a faze-lo depressa "para que ninguém chegue antes" (apud TAVARES, 2007, p. 69). Nesta mesma época, o jornal Praça de Santos era dirigido por Rafael Correa, jovem jornalista que mantinha relações políticas com ativistas de diversos meios, inclusive com Mário Pedrosa, 
que em carta a Lívio Xavier menciona o jornal local (NETO, 1993, p. 313). Pedrosa foi o principal introdutor das ideias de Rosa Luxemburgo no Brasil. Na década de 1940, o jornal Vanguarda Socialista, fundado por ele, publicaria ao menos 12 textos da autora em seus três anos de funcionamento. Para acrescentar mais um elemento à teia de possibilidades desse encontro, também no ano de 1931 foi publicada a Introdução à ciência do direito, de Hermes Lima, na qual ele "citava Rosa Luxemburgo contra o perigo da Ditadura do Proletariado tornar-se um governo de camaradas" (SECCO, 2017, p. 116).

O mapeamento é necessário para compreender qual o lugar de Rosa no imaginário coletivo do comunismo de então. Depois de seu assassinato em 1919, ela já era conhecida no país. Sua imagem, ao lado de Karl Liebknecht, como mártir da revolução atravessou o mundo. Marcos del Roio, por exemplo, acredita que o nome do jornal anarco-comunista Spartacus (que circulou no Rio de Janeiro no ano da morte dos dois) seja uma referência aos espartaquistas alemães (DEL ROIO, 2007). O editorial de estreia do jornal, entretanto, trata apenas do escravo romano ${ }^{4}$. Em fins dos anos 1920, o libertário comunista Antonio Bernardo Canellas publicou uma brochura que os homenageava.

A associação de Rosa Luxemburgo a uma concepção democrática de comunismo ganha maior concretude a partir da divulgação de suas polêmicas com Lenin e, sobretudo, após a publicação, em 1922, de seu texto sobre a Revolução Russa. O ano de 1924 dá início à mencionada bolchevização dos partidos comunistas, processo pelo qual o pensamento de Rosa entraria no rol de condenações do stalinismo. No ano de 1931, em uma carta que ganharia enorme importância, Stalin tenta explicar os fundamentos do leninismo e para tanto ataca seus reais ou potenciais adversários, entre eles a ideia de espontaneidade das massas. O texto permitiu ao Partido Comunista Alemão incluir o "luxemburguismo" entre os males a serem derrotados ou silenciados (LOUREIRO, 2009). Com isso, o pensamento de Rosa era posto na galeria do chamado social-fascismo, tese que, para além dos problemas de isolamento político resultantes, também serviu para perseguir divergências.

A presença de Rosa Luxemburgo em Parque industrial, portanto, não é trivial. Ela entra diretamente no romance como mártir, quando a personagem Otávia conta a história da revolucionária polonesa para o filho mais novo do personagem Alexandre, que ouvira de um colega que tal mulher nunca havia existido. Alexandre, na sequência narrativa, repetirá o martírio de Rosa. A personagem Rosinha Lituana também é uma homenagem, óbvia pelo nome e também por sua retidão militante e inabalável compromisso. Por fim, no que é mais importante para nós, Rosa Luxemburgo também entra na ação narrativa. A qualidade crítica da alusão à Rosa está na força coletiva do proletariado representado, bastante afim à ação espontânea. Esta escolha manifesta a complexidade de Parque industrial. Se, em sua superfície, o livro é mero "catecismo comunista", em sua
[4] Disponivel em http://segall. ifch.unicamp.br/ 
narrativa, ele disputa um ponto de vista dentro do discurso no qual está inserido, o que não é tarefa fácil para uma autora afastada oficialmente da organização. Parafraseando Isabel Loureiro na exposição e análise do modo como Luxemburgo articula as imagens de claro e escuro, sombras e iluminação, para se referir à ação política do proletariado russo na revolução de 1905 (LOUREIRO, 2004, p. 80), podemos dizer que no romance proletário de Pagu o trabalho da organização passa silencioso e discreto ao longo da leitura. Rosinha Lituana e Otávia operam no espaço sombreado dos bastidores, como no capítulo sobre o carnaval, em que elas estão ausentes para produzir panfletos. A obscuridade parece afetar tudo o que é aparente, não à toa o carnaval é mostrado como uma manifestação corrompida. Capítulos à frente, quando a greve irrompe, seu movimento traz consigo iluminação, não apenas na forma de consciência. "O Brás acorda!". A ação é luminosa porque é própria do proletariado.

Em Parque industrial, o espaço da fábrica é aterrador, pois tudo devora: as ruas, as pessoas, as vozes das pessoas. A fábrica é o lugar em que as máquinas têm vida e mortificam o trabalho vivo, é o lugar sombrio, por isso não espanta que o capítulo "Habitação coletiva" comece com os tanques de roupa do cortiço, onde "mãos esfoladas se esfolam" e as lavadoras conversam sobre a impossibilidade de criar os próprios filhos, sobre a"sedução das garotas do bairro", sobre a precariedade de suas moradias. Rosinha e Otávia chegam do trabalho e ajudam, com uma lata de leite condensado e outra de marmelada, uma mãe que já não consegue amamentar sua criança. As duas militantes conversam sobre o convencimento de Matilde, que já leu todos os panfletos que elas Ihe deram. A conversa das duas é atravessada pela voz do proprietário exigindo aluguel. “Todo o cortiço se lamenta." A narrativa então passa pela casa tabu do cortiço, onde mora d. Catita e "entram muitos homens", desloca-se para uma conversa entre crianças que começa ingênua e torna-se impudica, volta para os tanques, em que Ambrozina, uma moça de quem a mãe se orgulha por ser datilógrafa e ter bom salário é mencionada com desconfiança, tanto pelas personagens quanto pelo narrador. O capítulo faz uma crônica da vila operária, até que ocorre a troca de turno da fábrica mais próxima e o apito liberta "uma humanidade inteira que se escoa para as ruas da miséria" (p. 85). Do pedaço da fábrica que regressa ao cortiço, um grito interrompe a crônica: " - Ninguém trabalha amanhã!". Um outro grito reforça o chamado-comunicado ("— Ninguém!") e uma voz entre os tecelões, que "espumam ódio proletário", explica a revolta: "— Estão arrancando o pão de nossa boca! Não podemos consentir! Diminuíram mais! Cachorros!". Forma-se uma manifestação espontânea na frente da fábrica. Nem as personagens engajadas nem qualquer imagética do partido está presente no momento de deflagração da ação política. Os gritos são anônimos e reforçam o clima de uma revolta espontânea.

O partido aparece na forma de bandeira vermelha com foice e martelo logo 
depois, em uma assembleia que lota o largo (provavelmente da Concórdia, que é citado em capítulo posterior). O largo da Concórdia, a propósito, simboliza um local importante da memória das lutas operárias de São Paulo. Por ser um núcleo integrador do bairro, era local de agitação anarquista, tanto de italianos quanto de espanhóis ("Línguas atrapalhadas mas ardentes se misturam nos discursos"). Era comum que suas grandes reuniões terminassem em confronto aberto com a cavalaria policial, ironia histórica com o nome do espaço (SEVCENKO, 1999). Na porta da fábrica, a repressão assombra um grupo de operários e operárias. Uma delas, grávida, teme pela vida de seu companheiro e quer o fim da greve, no que uma voz doutrinária e inominada responde: — Que fraqueza, companheira! Neste momento todos lutam. Não há indivíduo. São todos proletários!". A fala é de um "operário sujo", qualificação ambígua, e seu arroubo classista não convence, pois as mulheres apoiam a "traição". A passagem é curta e a cena é rápida, mas não é pouco para um livro de propaganda. Rosinha decide então discursar e dirige-se aos presentes com didatismo. Ao fim da sequência narrativa, todos são alcançados pela repressão e o confronto se torna agudo: "Tiros, chanfalhos, gases venenosos, patas de cavalo. A multidão torna-se consciente, no atropelo e no sangue." (GALVÃO, 2006, p. 89, grifo nosso). A cena é ilustrativa: a vanguarda tem o papel do esclarecimento, a consciência, no entanto, é resultado da ação.

A complexidade de um romance como esse, embrenhado no pensamento de vanguarda de seu tempo, expõe uma verdade que, a seu modo, consegue driblar os chavões partidários que tremulam em sua superfície. A importação de ideias num país saído de uma situação colonial é um problema e tanto e perpassa a história, a literatura e o pensamento de esquerda no Brasil. A audácia de Patrícia Galvão, participante ativa do grupo antropofágico do modernismo e do movimento comunista na decisiva virada dos anos 1920 para os 1930, fica mais evidente em seu romance. Parque industrial é uma peça literária que condensa aspectos dessa transição, tanto política quanto artística. Figura, em meio ao discurso panfletário, os problemas do intelectual militante. Prefigura o stalinismo e, entretanto, retoma uma prática do anarco-sindicalismo. Faz propaganda do dogmatismo partidário, sobretudo pela fala de personagens comprometidos, mas impõe à ação narrativa uma nota divergente de amplitude libertária. Em matéria de confronto de posições, fundamento de riqueza da vida cultural e política das sociedades democráticas, este livro testemunha mais do que uma primeira visada pode supor. 


\section{REFERÊNCIAS BIBLIOGRÁFICAS}

ANDRADE, Homero Freitas de. "O realismo socialista e suas (in)definições". Literatura e sociedade, São Paulo, n. 13, p. 152-165, jun. 2010.

ANDRADE, Mário de. Aspectos da literatura brasileira. Belo Horizonte: Itatiaia, 2002.

ANDRADE, Oswald. Pau Brasil. São Paulo: Globo, 1990.

. Memórias sentimentais de João Miramar. São Paulo: Globo, 2000a.

Serafim Ponte Grande. São Paulo: Globo, 2000b.

ANDREUCCI, Álvaro G. A. O risco das ideias: intelectuais e a polícia política (1930-1945). São Paulo: Associação editorial Humanitas, 2006.

ASCHER, Nelson. "Originalidade de Pagu supera militância". Folha de S.Paulo, São Paulo, 10 abr. 1994. Caderno Mais.

BENJAMIN, Walter. A origem do drama barroco alemão. São Paulo: Brasiliense, 1985.

Magia e técnica, arte e política: ensaios sobre literatura e história da cultura. São Paulo: Brasiliense, 1994.

BOPP, Raul. Movimentos modernistas no Brasil - 1922-1928. Rio de Janeiro: José Olympio, 2012.

BRANDÃO, Gildo Marçal. As duas almas do Partido Comunista - 1920/1964. São Paulo: Hucitec, 1997.

BUENO, Luís. Uma história do romance de 30. São Paulo/Campinas: Edusp/ Unicamp, 2006.

BÜRGER, Peter. Teoria da vanguarda. São Paulo: Cosac Naify, 2008.

CAMILO, Vagner. Drummond: da Rosa do povo à Rosa das Trevas. Cotia: Ateliê editorial, 2001.

CAMPOS, Augusto de. Pagu: vida-obra. São Paulo: Brasiliense, 1982. 
Pagu: vida-obra. São Paulo: Companhia das Letras, 2014.

CANDIDO, Antonio. Literatura e sociedade. Rio de Janeiro: Ouro sobre Azul, 2006a.

A educação pela noite e outros ensaios. Rio de Janeiro: Ouro sobre azul, 2006b.

CARONE, Edgar. O marxismo no Brasil. Rio de Janeiro: Dois pontos, 1986.

A República Nova (1930-1937). São Paulo: Difel, 1982.

CARONE, Edgar. O PCB. São Paulo: Difel, 1982a.

DARNTON, Robert. Poesia e polícia. Redes de comunicação na Paris do século XVIII. São Paulo: Companhia das Letras, 2012.

DEAECTO, Marisa Midori; MOLLIER, Jean-Yves. Edição e revolução. Leituras comunistas no Brasil e na França. São Paulo/Belo Horizonte: Ateliê Editorial/ Editora UFMG, 2013.

DEL ROIO, Marcos. A classe operária na revolução burguesa. A política de alianças do PCB: 1928-1935. Belo Horizonte: Oficina de livros, 1990.

"A gênese do Partido Comunista". In: REIS FILHO, Daniel Aarão; FERREIRA, Jorge. (Org.). História das esquerdas no Brasil: a formação das tradições. v. 1. Rio de Janeiro: Civilização Brasileira, 2007.

DUARTE, Eduardo de Assis. Jorge Amado: romance em tempo de utopia. Rio de Janeiro: Record, 1996.

EAGLETON, Terry. Marxismo e crítica literária. São Paulo: Editora Unesp, 2011.

FACIOLI, Valentim. (Org.) Por uma arte revolucionária independente. Rio de Janeiro: Paz e Terra, 1985.

Serafim Ponte Grande: estrutura literária e dimensões ideológicas.

Dissertação. Mestrado em Teoria e História Literária. IEL. Unicamp, 1999.

GALVÃo, Patrícia. Paixão Pagu: a autobiografia precoce de Patrícia Galvão. Ferraz, Geraldo (org.). Rio de Janeiro: Agir, 2005.

GALVÃO, Patrícia (Mara Lobo). Parque industrial. Rio de Janeiro: José Olympio, 
2006.

FONSECA, Maria Augusta. Oswald de Andrade: biografia. São Paulo: Globo, 2007.

HOBSBAWM, Eric. Como mudar o mundo. São Paulo: Companhia das letras, 2013.

KAREPOVS, Dainis. A classe operária vai ao parlamento: O Bloco Operário Camponês do Brasil (1924-1930). São Paulo: Alameda, 2006.

KONDER, Leandro. A derrota da dialética: a recepção das ideias de Marx no Brasil até o começo dos anos 1930. São Paulo: Expressão Popular, 2009.

LAFETÁ, João Luiz. 1930: a crítica e o modernismo. São Paulo: Duas Cidades/ Editora 34, 2000.

"Modernismo setenta anos depois". In: In: MELHY, José Carlos Sebe Bom; ARAGÃO, Maria Lucia Poggi (Org.). América: ficção e utopia. São Paulo, Edusp/Rio de Janeiro/Expressão e Cultura, 1994.

LENIN. Que fazer? A organização como sujeito político. São Paulo: Martins Fontes, 2006.

LOUREIRO, Isabel. "Democracia e socialismo em Rosa Luxemburgo". Crítica Marxista, 45. Disponível em:

http://www.ifch.unicamp.br/criticamarxista/arquivos_biblioteca/artigo234_ Isabel.pdf. Acesso em: 3 fev. 2015.

LOUREIRO, Isabel (Org.). "A recepção de Rosa Luxemburgo na Alemanha". São Paulo: 2009. Disponível em: https://www.ifch.unicamp.br/formulario_cemarx/selecao/2009/trabalhos/arecepcao-de-rosa-luxemburgo-na-alemanha.pdf. Acesso em: 24 nov. 2017.

LOUREIRO, Isabel. Rosa Luxemburg: os dilemas da ação revolucionária. São Paulo: Editora da Unesp/Perseu Abramo/RLS, 2004.

LÖWY, Michael. "A centelha se acende na ação: a autoeducação dos trabalhadores no pensamento de Rosa Luxemburgo". Educação e Filosofia. Uberlândia, v. 28, n. 55, p. 27-38, jan.-jun. 2014. 
LUXEMBURGO, Rosa. Textos escolhidos. Organização de Isabel Loureiro. 2. v. São Paulo: Editora Unesp, 2011.

MANFRINI, Bianca Ribeiro. A mulher e a cidade: imagens da modernidade brasileira em quatro escritoras paulistas. São Paulo: Edusp, 2011.

MORAES, João Quartim de. História do marxismo no Brasil. Campinas: Editora Unicamp, 2007.

NAPOLITANO, Marcos; CZAJKA, Rodrigo, MOTTA, Rodrigo Patto Sá (org). Comunistas brasileiros: cultura política e produção cultural. Belo Horizonte: Editora UFMG, 2013.

., A relação entre arte e política: uma introdução metodológica.

Temáticas, Campinas, 19(37/38): 25-56, jan./dez. 2011.

NETO, José Castilho Marques. Solidão revolucionária: Mário Pedrosa e as origens do trotskismo no Brasil. Rio de Janeiro: Paz e Terra, 1993.

PACHECO, Ana Paula. "Cidade-cárcere: violência e representação das classes baixas na literatura brasileira contemporânea." Terceira Margem. v. 16. 2007.

"O vaqueiro e o procurador dos pobres: Vidas Secas". Rev. Inst. Estud. Bras., São Paulo, n. 60, p. 34-54, abr. 2015.

PINHEIRO, Paulo Sérgio. Estratégias da ilusão. A revolução mundial e o Brasil: 1922-1935. São Paulo: Companhia das Letras, 1992.

PRADO, Antonio Arnoni; HARDMAN, Francisco Foot; LEAL, Claudia. Contos anarquistas. São Paulo: Martins Fontes, 2011.

PRADO JR., Caio. Formação do Brasil contemporâneo. São Paulo: Brasiliense, 2004.

RICUPERO, Bernardo. Caio Prado Jr. e a nacionalização do marxismo no Brasil. São Paulo: Editora 34, 2000

SCHWARZ, Roberto. Que horas são? São Paulo: Companhia das letras, 2006.

SECCO, Lincoln. A batalha dos livros. Formação da esquerda no Brasil. São Paulo: Ateliê editorial, 2017. No prelo. 
INFLUXOS POLÍTICOS EM PARQUE INDUSTRIAL _ JOÃO CARLOS RIBEIRO JR. | 103

SEVCENKO, Nicolau. "São Paulo: não temos a menor ideia". Carta Capital, 29 set. 1999.

STRADA, Vittorio. “Do 'Realismo Socialista' ao Zdhanovismo". In: HOBSBAWN, Eric. História do Marxismo. v. 9. Rio de Janeiro: Paz e Terra, 1989.

TAVARES, Rodrigo Rodrigues. A "Moscouzinha" brasileira: cenários e personagens do cotidiano operário de Santos (1930-1954). São Paulo: Associação editorial Humanitas, 2007.

TROTSKY, Leon. Literatura e revolução. Rio de Janeiro: Zahar, 2007. 
